\title{
One month follow up of a neonate born to a mother who survived Ebola virus disease during pregnancy: a case report in the Democratic Republic of Congo
}

\author{
N. Kasereka Baraka ${ }^{1}$, Mupenzi Mumbere ${ }^{2^{*}}$ (i) and Evie Ndombe ${ }^{3}$
}

\begin{abstract}
Background: The authors report a 1 month follow up of a neonate described as "miracle baby" because she was born Ebola virus disease-free and survived after her mother was infected with Ebola virus during the third trimester of pregnancy.

Case presentation: This female newborn baby was registered at the Maternity of Beni Reference General Hospital and the Ebola Treatment Centre in eastern Democratic Republic of Congo. She was delivered normally and showed no signs of Ebola infection. All tests were negative for Ebola. At 1 month follow up, the baby is growing normally.

Conclusions: This very rare happy outcome for neonates of mothers infected with Ebola virus motivated the authors to report the case.
\end{abstract}

Keywords: Case report, Ebola virus, Neonate, Pregnancy, One month follow up

\section{Background}

According to the World Health Organization (WHO), Ebola virus disease (EVD) is a serious, highly contagious and fatal disease in humans. The virus is transmitted to humans from wild animals and spreads to the population through interpersonal transmission [1].

Ebola virus disease during pregnancy is associated with a very high rate of obstetric complications and perinatal adverse outcomes including spontaneous abortion, premature rupture of membranes, premature delivery, ante- and postpartum haemorrhage, intrauterine death of the foetus, maternal and neonatal death [2]. Neonates born to women with Ebola virus (EBOV) are often premature [3] and typically do not survive for more than a few weeks [4].

The data show that intrauterine content remains positive for Ebola virus ribonucleic acid (RNA) [5]. Since the identification of EBOV, 15 neonates born alive to

\footnotetext{
* Correspondence: mupenzimumbere@gmail.com

${ }^{2}$ Department of Paediatrics, Faculty of Medicine, Catholic University of

Graben, Butembo, Democratic Republic of the Congo

Full list of author information is available at the end of the article
}

EBOV-infected mothers have been documented. All died; the longest documented survival was 19 days [6].

During the 2014-2016 outbreak, Médecins Sans Frontières treated at least $54 \mathrm{EBOV}$-infected women with pregnancies in the second and third trimester and recorded 35 second-trimester miscarriages and deliveries in Ebola treatment centres. The single baby born alive died 2 days after birth. To date, there is only one survival beyond neonatal period reported in the literature about babies born to EBOV-infected women. It was a female baby born with congenital EVD who was followed up for 12 months of life in Conakry (Guinea) and was found to be growing normally [7]. While in a retrospective cohort study of patients managed at 5 Ebola Treatment Units (ETU) in West Africa, two neonates born live to EBOVinfected women in the ETU died within 8 days [8].

Here we report a 1 month follow up of a neonate born to a mother who survived the Ebola virus disease in eastern Democratic Republic of Congo during the Ebola outbreak that was declared in August 2018 and continues to wreak havoc in the northern areas of the

(c) The Author(s). 2019 Open Access This article is distributed under the terms of the Creative Commons Attribution 4.0 International License (http://creativecommons.org/licenses/by/4.0/), which permits unrestricted use, distribution, and reproduction in any medium, provided you give appropriate credit to the original author(s) and the source, provide a link to the Creative Commons license, and indicate if changes were made. The Creative Commons Public Domain Dedication waiver (http://creativecommons.org/publicdomain/zero/1.0/) applies to the data made available in this article, unless otherwise stated. 
province of Nord-Kivu and the neighbouring areas in the province of Ituri.

\section{Case presentation}

Our patient's mother, 22-year-old previously healthy multigravida woman (Para 4, Gravida 6, Abortion 1, Live children 4) was admitted to the Beni General Hospital Ebola Treatment Center 2 days after onset of symptoms (fever, vomiting and malaise) and was confirmed positive for EBOV by polymerase chain reaction (PCR). She reported a 34 week pregnancy and confirmed that the previous pregnancy follow up was uneventful. She was discharged after 1 week of management made of rehydration, Cefixime, Paracétamol and other supportive measures.

At the gestational age of 38 weeks, vaginal delivery occurred after a $10 \mathrm{~h}$ labor, the foetus was in breech presentation with meconial amniotic fluid and a normal placenta. The female newborn baby did well initially with an Apgar score of 8/9/10. General and neurologic examination did not reveal any pathology. The vital signs and anthropometric parameters at birth were as follows: temperature $36.5^{\circ} \mathrm{C}$, regular breathing at 52 cycles per minute and heart rate 146 beats per minute; weight of $3500 \mathrm{~g}$, head circumference of $36 \mathrm{~cm}$ and height of $53 \mathrm{~cm}$. The haemoglobin level was $16 \mathrm{~g} / \mathrm{dl}$; the umbilical cord blood PCR, the blood and salivary swabs were negative for the Ebola virus disease. She was subjected to an antibiotic therapy made of cefotaxime $(3 \times 200 \mathrm{mg} /$ day) and was discharged after 5 days.

At 1 month and 6 days of age, the baby was growing normally, she weighed $4100 \mathrm{~g}$ (versus $4400 \mathrm{~g}$ ideally), she was being breastfed and her mother reported no illness in the past days of her life.

\section{Discussion and conclusions}

We describe a neonate who was born EBOV-free from a mother who survived Ebola virus disease during her pregnancy in late stage. We think that this favourable outcome was probably due to the fact that the mother presented a relatively mild disease phenotype which was not transmitted to the foetus in utero.

Although information on the consequences of Ebola during pregnancy is limited (in terms of risk factors), early reports seemed to indicate very high mortality, which also leads to a fatalistic approach to the pregnant population management $[5,9]$. However in a retrospective cohort study of patients managed at five Ebola treatment units in West Africa, the data do not support the idea that pregnant women are at higher risk for death compared with nonpregnant patients with EVD [8].

According to very disturbing reports from West Africa, pregnant women suspected of having Ebola virus were denied access to health facilities because healthcare providers feared they would infect other patients. Because of the history of an almost uniformly fatal outcome in infants born to mothers with Ebola, these pregnant mothers and their infants have not been given the care needed [10]. However throughout the course of the epidemic, the situation improved over time [8].

Although these are very rare cases, some pregnant women have survived the Ebola virus disease without losing the unborn child. In a medical facility in developed countries, the chances of survival of a pregnant woman with Ebola virus disease could be high thanks to the implementation of standard supportive care. However, whether supportive care for neonates born to women infected with EVD would be effective in high income settings also remains to be seen [10].

Ebola virus disease remains a serious public health problem because of its high mortality and the fatal obstetrical and neonatal complications. Our case highlights the possibility of delivery and survival of disease-free full term babies born to mothers who survived the Ebola virus disease. Thus, care should be strengthened in pregnant women to improve the chances of saving neonates born in these conditions.

\section{Abbreviations \\ EBOV: Ebola virus; ETU: Ebola treatment unit; EVD: Ebola virus disease; PCR: Polymerase chain reaction; RNA: Ribonucleic acid; WHO: World Health Organization}

\section{Acknowledgements}

The authors are thankful to the team of the maternity of Beni General Hospital and Beni Ebola Treatment Centre for their crucial collaboration during the data collection process.

\section{Authors' contributions}

MM and NKB collected the data and wrote the first manuscript. NE critically reviewed the manuscript. All authors read and approved the final manuscript.

\section{Funding}

The authors did not need any specific funding to produce this case report.

\section{Availability of data and materials}

The datasets used and/or analysed during the current study are available from the corresponding author on reasonable request.

\section{Ethics approval and consent to participate}

This initiative to report the case was approved by the Ethics Committee of North-Kivu. Consent to participate was not applicable.

\section{Consent for publication}

The mother of the neonate provided a written consent for publication of this material.

\section{Competing interests \\ The authors declare that they have no competing interests.}

\section{Author details}

'Department of Paediatrics, Faculty of Medicine, University of Kalemie, Kalemie, Democratic Republic of the Congo. ${ }^{2}$ Department of Paediatrics, Faculty of Medicine, Catholic University of Graben, Butembo, Democratic Republic of the Congo. ${ }^{3}$ Department of Obstetrics and Gynaecology, Faculty of Medicine, University of Kalemie, Kalemie, Democratic Republic of the Congo. 
Received: 19 February 2019 Accepted: 12 June 2019

Published online: 18 June 2019

\section{References}

1. OMS. Prévention et contrôle de l'infection pour les soins aux cas suspects ou confirmés de fièvre hémorragique à filovirus dans les établissements de santé, avec un accent particulier sur le virus Ebola. Genève: Guide provisoire; 2014.

2. Baggi F M, Taybi A, Kurth A, Van Herp M, Di Caro A, Wölfel R, Günther $S$, Decroo T, Declerck $H$, Jonckheere $S$. Management of pregnant women infected with Ebola virus in a treatment centre in Guinea, June 2014. Euro Surveill 2014;19(49):pii=20983. https://doi.org/10.2807/15607917.ES2014.19.49.20983.

3. Wamala JF, Lukwago L, Malimbo M, Nguku P, Yoti Z, Musenero M, et al. Ebola hemorrhagic fever associated with novel virus strain, Uganda 20072008. Emerging Infect Dis. 2010;16(7):1087-92.

4. Francesconi P, Yoti Z, Declich S, Onek PA, Fabiani M, Olango J, et al. Ebola hemorrhagic fever transmission and risk factors of contacts, Uganda. Emerging Infect Dis. 2003;9(11):1430-7.

5. Jameison DJ, Uyeki TM, Coologhan WM, Meaney D, Rasmussen SA. What obstetrician-gynecologist should know about Ebola; a perspective from the center for disease control and prevention. Obstest Gynecol. 2014;124:1005-10

6. Nelson JM, Griese SE, Goodman AB, Peacock G. Live neonates born to mothers with virus disease: a review of the literature. J Perinatol. 2015;36:411-4.

7. Dornemann J, Burzio C, Ronsse A, Sprecher A, De Clerck H, Van Herp $M$, et al. First newborn baby to receive experimental therapies survives Ebola virus disease. J Infect Dis. 2017;215(2):171-4. https://doi.org/10. 1093/indidis/jiw493.

8. Henwood PC, Bebell LM, Roshania R, et al. Ebola virus disease and pregnancy: a retrospective cohort study of patients managed at 5 Ebola treatment units in West Africa. Clin Infect Dis. 2017;65(2):292-9.

9. Mupapa K, Mukundu W, Bwaka MA, Kipasa M, De Roo A, Kavula K, et al. Ebola hemorrhagic fever and pregancy. J Infect Dis. 2000;179:22-3.

10. Lang, J. Ebola in the maternity ward. New York. 2014. http://www.new yorker.com/com/tech/elements/ebola-ward. Accessed 02 Feb 2019.

\section{Publisher's Note}

Springer Nature remains neutral with regard to jurisdictional claims in published maps and institutional affiliations.

Ready to submit your research? Choose BMC and benefit from:
- fast, convenient online submission
- thorough peer review by experienced researchers in your field
- rapid publication on acceptance
- support for research data, including large and complex data types
- gold Open Access which fosters wider collaboration and increased citations
- maximum visibility for your research: over 100M website views per year
At BMC, research is always in progress.
Learn more biomedcentral.com/submissions

